\title{
Využití postupů rozhlasové detektivky za hranicemi žánru
}

Detektivní př́běh jako žánr se napříč všemi uměleckými druhy, do kterých zasahuje, vyznačuje využíváním celé řady zažitých a neustále opakovaných schémat. Ta jsou pak v závislosti na různé míře kreativity daných autorů variována s větší či menší invencí, jež je v rozhlasovém prostředí rozšířena ještě o autorský vklad inscenačního týmu, který se na adaptaci detektivní prózy podílí. Důležitou okolností, jež ovlivňuje tyto opakující se postupy, motivy a náměty, je recipientovo očekávání, zkušenost s daným žánrem a vůbec celá recepční aktivita. Tyto faktory totiž v největší míře působí na určitou schematičnost detektivních prríběhů, které aby mohly být přijaty a vnímány jako detektivka, musí vykazovat její jasné rysy. Ty představují u rozhlasových detektivek například achronologický způsob vyprávění příběhu, hlavní hrdina - detektiv - podílející se aktivně na vyšetřování záhadné události, příčina veškerého děje v podobě postavy zločince, bohatý zvukový plán, díky kterému jsou plasticky vykreslena místa děje, práce s napětím a s posluchačským očekáváním a v neposlední řadě také s momentem překvapení. Tyto postupy mohou být obsaženy již v textu předlohy rozhlasové adaptace, ale bývají také významnou měrou vytvářeny v rámci auditivního zpracování.

Postupy a prvky typické pro žánr rozhlasové detektivky se však úspěšně uplatňují také v inscenacích mimo toto žánrové vymezení. Jde například o některé hry filozofického či společensko-kritického charakteru, jejichž narativ se může inspirovat modelem vyšetřování, tedy postupným odhalováním skutečností recipientovi. Podobně jako u detektivky také $\mathrm{v}$ dílech mimo toto žánrové vymezení se v rozhlase pracuje s vytvářením napětí, jeho udržením a stupňováním. Právě vzbuzení pocitu napětí u posluchače predpokládá jeho plné zapojení do procesu vnímání příběhu. Motivy 
a postupy rozhlasových detektivních př́běhů nalézáme také v širším okruhu rozhlasových her, jež jsou adaptacemi klasické literatury. Prvky detektivního žánru zde mohou být zakořeněny již v samotném textu předlohy a přejímá je i rozhlasová adaptace. Jednou z nejvýraznějších stylotvorných charakteristik je koncipování do podoby achronologicky vyprávěného př́běhu s tajemstvím, z něhož se detektivka také zrodila. Předpokladem je př́tomnost určité myšlenky či informace, jež má být sdělena až na samém konci díla, které $\mathrm{k}$ tomuto závěrečnému odhalení po celou dobu spěje. $\mathrm{V}$ tomto ohledu disponuje auditivní podoba díla zvukovými možnostmi, které mohou výrazně podpořit vytváření napětí či momentů překvapení a pomoci tak gradování děje.

Cílem tohoto př́spěvku je ukázat, jakým způsobem a z jakých důvodů mohou být některé inscenační postupy typické pro rozhlasovou detektivku využity v dílech mimo toto žánrové vymezení. Předpokládanou motivací pro užití prvkủ jako stupňování napětí či narativní rámec policejního vyšetřování je účinek na posluchače a jeho recepční aktivitu. Tzv. bílá místa v narativu př́běhu, snaha podílet se (alespoň domněle) na vyšetřování záhadné události či pokusy odhadnout dopředu budoucí dění, to vše představuje větší a aktivnější mentální zapojení posluchače při vnímání díla, a tedy jeho zvýšený zájem o něj. Dá se říci, že prostředky detektivního žánru takto umožňují dílo určitým způsobem posluchačsky zatraktivnit.

Hlavním aspektem, kterým se tyto rozhlasové hry s prvky detektivního žánru odlišují od čistě detektivních př́iběhů, je záměr obsažený většinou již v textech jejich literárních předloh. Detektivka bývá zaměřena na propracování samotné záhady, na její detaily a snaží se recipienta zaujmout spíše jako forma zábavné hádanky. Každý př́běh pak disponuje vlastní poetikou lišící se v závislosti na stylu jednotlivých autorů a na době vzniku díla. Agatha Christie své povídky zasazuje do prostředí idylického anglického venkova slečny Marplové, která jakoukoliv záhadu objasní mezi dvěma šálky odpoledního čaje, Sherlock Holmes Arthura Conana Doyla zase stíhá zločince v ulicích Londýna 19. století a moderní severské detektivky daleko více staví na vnitřních motivacích zločinců a odcizené anonymitě velkoměst. Současně však těží z jisté formy obeznámenosti recipienta s žánrem a možnosti srovnávat, jak jednotliví autoři s žánrovými konvencemi detektivky nakládají.

Cílem rozhlasové hry s prvky detektivního žánru však není v prvé řadě rozkrytí tajemné záhady a demonstrace výjimečných detektivových deduktivních schopností, nýbrž sdělení filozofického či společensko-kritického charakteru. Kriminální př́běh tedy tvoři pouze kulisy a prostředky autorova sdělení a úvah. Př́kladem může být dílo Gilberta K. Chestertona, jehož povídky balancují na pomezí detektivky a filozofického zamyšlení: „Zločin a jeho odhalení jsou předpokladem úvahy o slabosti člověka.." (GRYM 1988: 109) Jeho př́běhy s otcem Brownem coby detektivem sice řadíme mezi detektivní prózu, ale např́ílad novela Anarchista Čtvrtek (1908) využívá rámec téměř detektivního pátrání pro úvahu nad stavem tehdejší občanské společnosti: „Nemalou pozornost si získal román Anarchista Čtvrtek, překvapujícími zvraty nabitý prŕběh o radě anarchistů, 
do níž se vloudí převlečený policista. Od tápání a zmatku vede tu Chesterton své hrdiny ke klidu, míru a ustálenému pořádku s neochvějnou vírou, že každý chaos lze překonat." (GRYM 1988: 108) Hlavní postavou přiběhu je básník a policista Gabriel Symon, jehož úkolem je se v zájmu státní bezpečnosti infiltrovat do nebezpečné anarchistické organizace. Podaří se mu probojovat mezi členy užšího vedení skupiny, ale při společné prípravě atentátu pomalu vyplouvá na povrch, že zde zdaleka není jediným policistou $\mathrm{v}$ př̀strojení.

Rozhlasová dramatizace této Chestertonovy fantastické novely vznikla ve spolupráci Zdeňka a Marie Hořínkových a pro rozhlas ji zpracoval režisér Ivan Chrz. Ten v inscenaci zdůraznil prvky absurdity a grotesknosti, kterou s sebou nese překvapivý závěr. Vliv detektivního žánru se projevil především v akční scéně noční honičky Londýnem, která vrcholí právě nečekaným odhalením jednoho z infiltrovaných policistů.

Dalším rozhlasovým dílem, jehož auditivní zpracování využívá detektivní postupy, je adaptace existencialistického románu Alberta Camuse Cizinec (1942) z roku 2000, jež předkládá děj knihy v podobě soudní rekonstrukce vraždy, které se dopustil hlavní hrdina. Jitka Škápíková ve své dramatizaci propojila dvě části románu: události před vraždou a pobyt ve vězení při čekání na výkon rozsudku smrti. V rozhlasovém zpracování se oba tyto celky prolínají prostřednictvím retrospektivních návratů k událostem, o kterých se právě hovoří. Rámec vyprávění tvoří samotný soudní proces, během kterého je vyslýchán jak hlavní hrdina, tak některé další postavy př́iběhu.

Titulní postavou děje je úřredník Mersault (Ivan Trojan), jenž je zároveň subjektivním vypravěčem př́běhu. $V$ introspektivních promluvách posluchači přibližuje nejen situaci, které bude následně účasten, ale také své niterné pocity a úvahy. Podobně jako u syžetu detektivních príběhů je posluchač vržen prrímo doprostřed děje - zde soudního jednání - a neví, jaké události tomuto dění předcházely. Až postupným rekonstruováním jednotlivých situací se skládá celková podoba fabule. Úvodní Mersaultovu promluvu tvoř́ úvaha nad jeho životem ve vězení. Ta je přerušena zvukovým předělem, kterým je neustále se vracející leitmotiv mořského př́boje. Jeho význam je symbolicky završen až v závěru př́běhu, kdy se posluchač dozvídá, že vražda se udála na mořském pobřeží. Po úvodním monologu se náhle ocitáme v soudní síni, jejíž atmosféru nám hlavní hrdina opět detailně popíše. Důraz na barvité vykreslení atmosféry je dalším prvkem charakteristickým pro žánr detektivní prózy. Poutavý a důkladný popis místa či míst děje je součástí snahy o realistickou kulisu, na jejímž pozadí se zápletka odehrává, a které mají recipienta vtáhnout do děje a přinutit jej $\mathrm{k}$ mentální participaci. V Camusově románu, a následně i v jeho rozhlasové adaptaci, je důležitým prvkem dotvářejícím atmosféru prostř̌edí slunce a teplo, které je často zdůrazňováno v Mersaultově vyprávění. Vzhledem k tomu, že jde o introspektivní promluvy, vzniká tak až citelný dojem horkého dusného prostředí, které hrdinu postupně a „př́mo před námi“ připravuje o rozum.

První část soudního vyšetřování, jemuž dominuje autoritativní hlas předsedy senátu (Jaromír Meduna), se neustále točí kolem Mersaultova vztahu k nedávno zemřelé matce. 
Žalobci usilují o představení úředníka coby bezcitného člověka, který umístil svou matku do útulku pro staré, nenavštěvoval ji a na jejím pohřbu neprojevoval známky zřejmého zoufalství. Soudní tribunál je zvukově ztvárněn pouze pomocí hereckých představitelů, jež se se svými naléhavými promluvami obrací na Mersaulta, ale přitom i jakoby na nás - posluchače, nebot dotyčný nahlas téměř neodpovídá. To jen podněcuje jeho žalobce, jejichž výroky přicházející ze všech stran nabírají postupně na intenzitě a z tónu hlasů lze vyčíst netrpělivost, rozhořčení i posměch. Mersault je po celou dobu napadán a osočován $\mathrm{z}$ nemorálního chování vůči své matce a její památce a zmínka o vraždě, kterou měl hlavní hrdina vykonat, padne až téměř v polovině stopáže rozhlasové hry. Zde si můžeme všimnout dalšího typického postupu převzatého $\mathrm{z}$ detektivního žánru: podstatná informace je posluchači nějakou dobu zamlčována a jeho pozornost je soustavně odváděna jinam, takže když je mu nakonec sdělena, vyvolá v něm o to větší překvapení.

Následně se retrospektivní návraty $\mathrm{k}$ předešlým událostem začnou točit kolem okolností vraždy, kterými bylo v prvé řadě seznámení Mersaulta se sousedem Raymondem a konflikt se skupinou Arabů, z nichž jeden je bratrem Raymondovy milenky. Poté, co se s nimi Mersault a Raymond náhodně potkají na břehu moře, dojde $k$ potyčce, př́i níž je Raymond zraněn, a Mersault pod dojmem všech těchto událostí jednoho z Arabů zastřelí. Dramatická situace, během níž dojde $\mathrm{k}$ vraždě, je detailně popsána $\mathrm{z}$ pohledu hlavního hrdiny, který ji líćí jakoby s odstupem a bez emocí, jako něco, co se událo velmi dávno. Jeho popis má takřka až snový charakter, který koresponduje s všudypř́tomným, sluncem rozpáleným prostředím vzbuzujícím pocit malátnosti a ztráty kontroly nad sebou samým. Náhled do zločincovy mysli, který recipientovi přibližuje pohnutky jeho jednání, slouží v detektivních příbězích jako prostředek $\mathrm{k}$ vytvoření plastické a uvěřitelné postavy, jejíz čin je podložen autenticky působícími motivacemi.

Poté, co se posluchač dozví o Mersaultově vině, stupňuje se agresivita jeho výslechu u soudu. Žalobci se jej snaží ukázat v souvislosti s jeho vztahem k matce jako necitlivého a nemorálního člověka, který je schopen chladnokrevné vraždy. Čím více se tento tlak stupňuje, tím více se Mersault uzavírá do sebe a pouze posluchač je obeznámen s jeho niternými úvahami, v nichž se vrací k lidem, které zná (např́klad milenka Marie), či $\mathrm{k}$ rozhovorům $\mathrm{s}$ knězem ve vězení. Přes veškerou snahu obhajoby je nakonec Mersault odsouzen k smrti.

Rozhlasová adaptace Cizince pracuje po vzoru detektivních př́běhů především s metodami vytvoření napětí a jeho udržení po celou dobu trvání díla. Výrazně při vytváření napětí pomáhá segmentace děje do kratších a dynamicky vystavěných scén. Tyto jednotlivé výjevy poskytují dílčí informace o události, která se stala, a posluchač se tedy o ní dozvídá až na základě těchto indicií. Velmi zajímavá je z hlediska stupňujícího se napětí scéna v márnici, kam se má jít Mersault podívat na svou mrtvou matku. Dramatické vyznění situace je určeno místem děje, ale také hudebním podkresem. Posluchač je po celou dobu trvání rozhovoru hrdiny se správcem, který jej do místnosti přivedl, udržován v napětí, jež není opodstatněno reálným děním, nebơ celá scéna je tvořena 
pouze úsečným dialogem Mersaulta se správcem a dlouhými pomlkami mezi jednotlivými promluvami. Posluchačův pocit napětí tedy plyne především z toho, co „by se mohlo stát“. O to více je překvapivé, když se v dalším obraze posluchač spolu s hrdinou vrací zpět do soudní síně, jako by se nic nestalo a gradované napětí okamžitě mizí.

Další významnou rozhlasovou inscenací využívající postupy detektivního žánru je adaptace novely Friedricha Dürrenmatta Soudce a jeho kat. Tento takřka detektivní př́íběh s filozofickými přesahy pro rozhlas upravili Jaroslava Strejčková a režisér Josef Henke. Hlavním hrdinou př́běhu je komisař Bärlach (Rudolf Hrušínský), starý a zkušený kriminalista sužovaný těžkou nemocí. Příběh, který zpočátku budí dojem klasického detektivního vyšetřování, však postupně přechází v důmyslnou psychologickou hru s filozofickým přesahem: „Autor předkládá svému čtenáři (a dramatizátor i posluchači) otázku - je morálně ospravedlnitelné vzít spravedlnost do svých rukou v okamžiku, kdy běžné policejní a justiční postupy selhávají? Je správné využít někoho k,neoficiálnímu' vykonání rozsudku?" (HNILIČKA 2013: 25) Komisař se totiž již řadu let snaží zatknout svého bývalého známého, inteligentního zločince, který ze svých činů nikdy nebyl usvědčen. Bärlach využije svého pomocníka Tschanze (Václav Postránecký), který je nakonec donucen zločince zabít, aby za něj vykonal pomstu.

Jedno z hlavních témat Dürrenmattova díla je polemika o morálních zásadách člověka. Dílčí otázky jsou formulovány především ústy komisaře Bärlacha, jehož představitel Rudolf Hrušínský dokázal svým nízko posazeným hlasem přesvědčivě ztvárnit hluboké zamyšlení i celkovou skepsi ze stavu společnosti. Kontrastně pak vyznívají situace, kdy kriminalista $\mathrm{v}$ rychlém sledu a rozhodným ostrým hlasem udílí pokyny podřízenému. $\mathrm{Z}$ jeho unaveného ochraptělého hlasu slyšíme také odraz hercova fyzického stavu, jemuž $\mathrm{v}$ době natáčení zbýval necelý rok života.

Kompozice této inscenace je takřka totožná s běžnou rozhlasovou detektivkou, od níž se však odlišuje větším množstvím introspektivních pasáží, dávajících nahlédnout do myšlenkových pochodů postavy detektiva. Tento postup by tvořil v čistě detektivních dílech nedynamické a zpomalující pasáže, ale v adaptaci Dürrenmattovy filozofické novely působí zcela funkčně.

Dokladem toho, jak může využití detektivních postupů v rozhlasové inscenaci primárně filozofického literárního díla pozměnit jeho strukturu, je adaptace prvního dílu tzv. noetické trilogie Karla Čapka Hordubal (1933). Dílo tohoto spisovatele akcentuje především filozofické a společenskokritické roviny, nicméně vliv formátu detektivky je nepopiratelný. Do auditivní podoby byl u nás Hordubal adaptován pouze jako audiokniha zahrnující i obě další části trilogie. Samotnou první část uvedl Slovenský rozhlas Košice v roce 1990 v režii Andreje Medvece. V inscenaci se za účelem vytvoření tíživé až nepřátelské atmosféry pracuje se stupňujícím se napětím v hlasech protagonistů, které ještě umocňuje minimalistická zvuková stopa v zadním plánu vedených dialogů. Z rozhovorů je jasně patrná prvotní odtažitost při rozpačitém přivítání Juraje Hordubala doma, která místo toho, aby se postupně změnila $v$ srdečnost, stává se ještě více 
chladnou. Přesto přichází Jurajova smrt zcela nečekaně. S ní se pak mění i atmosféra inscenace $\mathrm{z}$ vesnického dramatu na profesionální vyšetřování vraždy. Toho se ujímají dva četníci, kteři ve svých hovorech problematizují možné motivy, jež k vraždě mají zúčastněné osoby. Zároveň se snaží celou událost posoudit i očima potenciálních pachatelů podobně jako v Čapkově novele. Profesionální přístup policistů, jež zde mají představovat spravedlnost, a tedy akceptovat pouze objektivní pravdu, je zase zproblematizován postojem jednoho z nich - staršího náčelníka vesnické policie, který chce celý př́pad spíše ututlat a využít informace, že by Hordubal stejně ve velmi krátké době zemřel na následky zápalu plic. Následný soud s manželkou a jejím milencem je v rozhlasové inscenaci pouze zmíněn v závěrečné řeči policisty, který o něm vypráví jakoby s profesionální nezaujatostí. Tempo inscenace se $\mathrm{v}$ této třetí ćásti opět mění, dynamický charakter procesu vyšetřování je vystřídán klidnější fází po skončení dramatu, ve kterém je hodnoceno předchozí dění a vyvozeno morální ponaučení.

Rozhlasová inscenace akcentuje rovinu vyšetřování, ve které se snaží postihnout i zmnožené hledisko vyprávění. $Z$ díla se však vytrácí filozofický charakter, jenž mu vtis$\mathrm{kl}$ autor literární předlohy. Rozhlasový Hordubal pouze přebírá detektivní rámec př́běhu, který ochuzuje o původní vyznění.

Jak lze vidět, specifika detektivního žánru v rozhlasovém prostředí jsou často využívána a různě modifikována i za hranicemi tohoto vymezení. Uvedené př́iklady potvrzují skutečnost, že postupy užívané především $\mathrm{v}$ detektivkách mohou být plně funkční i v rozhlasových inscenacích her jiného žánru a charakteru, v nichž pak mohou fungovat jak ve složce vyprávění, tak např́klad ve složce zvukové.

\section{Bibliografie}

GRYM, Pavel. 1988. Sherlock Holmes a ti druzí: čtení o detektivech a detektivkách [Sherlock Holmes and the Others. Reading About Detectives and Detective Stories]. 1. vyd. Praha: Vyšehrad, 1988.

HNILIČKA, Přemysl. 2013. Jen rok. Už jenom rok [A Year. Just One Year]. Týdeník rozhlas 13 (2013): 48: 25.

DOI: 10.5817/TY2015-1-6 